\title{
Genetic Instability of R Plasmids in Relation to the Shift of Drug Resistance Patterns in Salmonella johannesburg
}

\author{
By P. Y. CHAU, ${ }^{1 *}$ JULIA LING $^{1}$ E. J. THRELFALL ${ }^{2}$ AND \\ S. W. K. IM ${ }^{1}$ \\ ${ }^{1}$ Department of Microbiology, University of Hong Kong, Hong Kong \\ ${ }^{2}$ Division of Enteric Pathogens, Central Public Health Laboratory, Colindale Avenue, \\ London NW9 $5 H T$, U.K.
}

(Received 8 May 1981; revised 17 June 1981)

\begin{abstract}
Observation of the resistance of Salmonella johannesburg to the six drugs ampicillin (A), streptomycin (S), tetracycline (T), chloramphenicol (C), kanamycin (K) and sulphadiazine (Su) was made over the 7 years from 1973 to 1979. Strains with ASTCKSu- and ASCKSu-resistance patterns predominated in the years 1973-1975 and 1976-1979, respectively. These resistances were found to be mediated by autotransferring plasmids belonging to the incompatibility group FIme. The ASTCKSu-resistance plasmids were unstable, giving rise to deletion variants at a much higher frequency than ASCKSu-resistance plasmids either of natural origin or derived in vitro from the ASTCKSu-resistance plasmids. Thus, the ASCKSu-resistance plasmid might be a deletion variant of the ASTCKSuresistance plasmid. This is supported by the extensive similarity of their cleavage patterns produced by specific restriction endonucleases.
\end{abstract}

\section{INTRODUCTION}

The FIme group of plasmids of Salmonella was first described and defined in detail by Threlfall et al. (1976) and Anderson et al. (1977). These large single-copy plasmids conferred multiple antimicrobial drug resistance, including resistance to ampicillin and chloramphenicol, and were identified in Salmonella species isolated in many countries of the Middle East, as well as in North Africa, France and Britain. One characteristic of these plasmids was that the resistance determinants underwent spontaneous segregation. Thus, although the majority of the plasmids coded for resistance to ampicillin (A), streptomycin (S), tetracycline $(\mathrm{T})$, chloramphenicol $(\mathrm{C})$, kanamycin $(\mathrm{K})$ and sulphadiazine $(\mathrm{Su})$ in the host bacterial cells, others showed different combinations of drug resistance, e.g. ASCKSu, ACKSu, etc. Both autotransferring and non-autotransferring members of the FIme group have been found; the latter were also of the large single-copy type and were thought to be transfer-defective deletion mutants (Willshaw et al., 1978).

Salmonella johannesburg was prevalent in Hong Kong from 1973 to 1977 following its introduction to this locality in 1972 , but the frequency of isolations has subsequently declined. During this period we observed a dramatic change in the patterns of drug resistance, apparently not related to the use of antimicrobial drugs (Chau et al., 1978). This communication describes the spontaneous evolution of drug resistance patterns coded for by FIme plasmids that have been identified in S. johannesburg during its emergence, prevalence and disappearance in a defined locality, Hong Kong, over a period of 7 years.

\section{METHODS}

Bacterial strains and plasmids. Strains of $S$. johannesburg were isolated in the paediatric wards of a general hospital in Hong Kong from 1973 to 1979. All the strains were stored in agar stabs after inoculation from single colonies. 
The recipient strain used in transfer experiments (see below) was an Escherichia coli K12, plasmid-free, rifampicin-resistant mutant Jp995 (Lac ${ }^{+}$, prototroph, $\mathrm{F}^{-}, \lambda^{-}, \mathrm{Rif}^{\mathrm{R}}$ ) supplied by Professor A. J. Pittard, Department of Microbiology, University of Melbourne, Australia.

Reference plasmids for incompatibility grouping provided by Professor A. J. Pittard and by Dr R. W. Hedges, Royal Postgraduate Medical School, London, U.K., included representatives of the following groups (the name of the plasmid and its $\mathrm{R}$ type are given in parentheses): C (R40a, AKS), FI (R386, T), FII (R1-16, K), FIV (R124, T), H (R27, T), I $\alpha$ (R144 drd 3, K), I $\gamma$ (R621a, T), J (R391, K), K (R387, CS), M (R446b, ST), P (RP4, AKT), T (Rts 1, K), V (R753, ACSSu), W (S-a, CKSSu) and X (R6K, AS). Plasmids from the collection of the Division of Enteric Pathogens included F-lac and F-T, the FIme plasmid TP243 (K) and the MP10 plasmid K-MP10 (Smith et al., 1973).

Plasmids used for molecular size determination were supplied by $\mathrm{Dr}$ E. M. Lederberg, Plasmid Reference Center, Stanford University, Calif., U.S.A.

Tests for drug resistance and conjugation experiments. Tests for the susceptibility of bacterial strains to various antimicrobial drugs and for the transfer of drug resistance were performed as described previously (Chau et al., 1978). After overnight matings, transconjugants were selected on MacConkey medium containing ampicillin $\left(25 \mu \mathrm{g} \mathrm{ml}^{-1}\right)$ and chloramphenicol $\left(25 \mu \mathrm{g} \mathrm{ml}^{-1}\right)$ while the donor strains were counterselected with rifampicin $\left(25 \mu \mathrm{g} \mathrm{ml}^{-1}\right)$. Colonies appearing on the selective media were purified on the same medium and their drug susceptibility was tested. The frequency of transfer of resistance was taken as the ratio of transconjugant colonyforming units (c.f.u.) to recipient c.f.u.

Tests for the stability of plasmids. Each of the 12 plasmid-carrying bacterial strains randomly selected in this study (see Table 3 ) was inoculated into $3 \mathrm{ml}$ nutrient broth and the culture was incubated for $24 \mathrm{~h}$. A sample of $0 \cdot 1$ $\mathrm{ml}$ of a $10^{-5}$ dilution of the first overnight culture (regarded as the first subculture) was inoculated into $3 \mathrm{ml}$ fresh nutrient broth, and this propagation was continued for $5 \mathrm{~d}$. Discrete colonies from each subculture were obtained by plating $0.1 \mathrm{ml}$ of a $10^{-7}$ or $10^{-8}$ dilution of the culture on Mueller-Hinton agar (Oxoid). From each subculture, 80-100 colonies were tested for antibiotic susceptibility by replica plating.

Incompatibility grouping. The $\mathrm{R}$ plasmid under study was transferred from $S$. johannesburg to E. coli Jp995, and the resulting strain was used as the recipient in matings with rifampicin-sensitive $E$. coli donor strains, each harbouring a plasmid of known incompatibility group. In cases when the drug resistance markers of an $\mathrm{R}$ plasmid under investigation overlapped with those of the reference plasmid, segregants of the plasmid lacking resistance markers of the reference plasmid were used in mating experiments. To select for transconjugants, the mating mixtures were plated on selective media containing rifampicin and a drug to which the incoming plasmid, but not the resident plasmid, specified resistance. Colonies appearing on selective media were purified by replating on similar media. At least 40 colonies were purified and tested for the presence of both the incoming and resident plasmids.

Phage typing. For phage typing studies, plasmids were transferred from $E$. coli $\mathrm{K} 12$ lines into standard strains of Salmonella typhimurium phage type 36 or Salmonella typhi Vi-phage type A. Colicin E2 was used for counterselection. The $S$. typhimurium transconjugants were phage typed by the method of Callow (1959) as extended by Anderson (1964) and the plasmid-carrying strains of $S$. typhi type A were phage typed by the method of Craigie \& Felix (1947).

Gel electrophoresis of plasmid DNA. Plasmid DNA was extracted according to the method of Hansen \& Olsen (1978). Electrophoresis was carried out in $0.9 \%(w / v)$ agarose slab gels $(120 \times 140 \times 3 \mathrm{~mm})$ at $50 \mathrm{~mA}$ for $2 \mathrm{~h}$ in a Tris/borate/EDTA buffer system (Greene $e$ t al., 1974) as described by Willshaw et al. (1979).

Restriction enzyme digestion of plasmid DNA. Purified plasmid DNA was prepared according to the method of Humphreys et al. (1975). Digestion of purified plasmid DNA by restriction endonuclease EcoRI or HindIII was carried out at $37^{\circ} \mathrm{C}$ for $30 \mathrm{~min}$, with an appropriate amount of DNA and an excess of enzyme. The reaction mixture for $E c o R I$ digestion contained $50 \mathrm{mM}-\mathrm{NaCl}, 100 \mathrm{mM}$-Tris/ $\mathrm{HCl} \mathrm{pH} 7.5$, and $100 \mu \mathrm{g}$ bovine serum albumin (BSA) $\mathrm{ml}^{-1}$. For HindIII digestion, the reaction mixture contained $60 \mathrm{mM}-\mathrm{NaCl}, 70 \mathrm{mM}-\mathrm{MgCl}_{2}, 70 \mathrm{mM}-\mathrm{Tris} / \mathrm{HCl}$

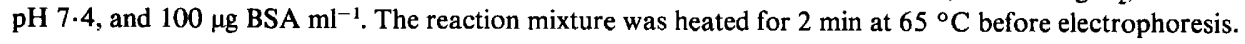

\section{RESULTS AND DISCUSSION}

\section{Shift in the antimicrobial drug resistance patterns in S. johannesburg in Hong Kong}

The predominant pattern of drug resistance in $S$. johannesburg changed over the period 1973-1979 (Table 1). During the first 3 years after this organism was introduced and became widespread in Hong Kong, 44-53\% of the isolates were found to be resistant to six drugs: A, $\mathrm{S}, \mathrm{T}, \mathrm{C}, \mathrm{K}$ and $\mathrm{Su}$. In later years, however, most strains were resistant to $\mathrm{A}, \mathrm{S}, \mathrm{C}, \mathrm{K}$ and $\mathrm{Su}$, but susceptible to $T$. In addition, the number of strains with other patterns of drug resistance was dramatically reduced. 
Table 1. Alteration of predominant patterns of drug resistance in S. johannesburg

\begin{tabular}{|c|c|c|c|c|c|c|c|}
\hline Year & 1973 & 1974 & 1975 & 1976 & 1977 & 1978 & 1979 \\
\hline $\begin{array}{l}\text { Total no. of strains examined } \\
\text { No. of strains* with resistance } \\
\text { pattern: }\end{array}$ & 63 & 51 & 124 & 118 & 26 & 12 & 3 \\
\hline ASTCKSu & $28(44)$ & $27(53)$ & $59(48)$ & $5(4)$ & 0 & 0 & 0 \\
\hline $\mathrm{ASCKSu}$ & 0 & 0 & $17(14)$ & $105(89)$ & $26(100)$ & $12(100)$ & $3(100)$ \\
\hline $\begin{array}{l}\text { No. of strains* with other } \\
\text { resistance patterns }\end{array}$ & $35(56)$ & $24(47)$ & $48(38)$ & $8(7)$ & 0 & 0 & 0 \\
\hline
\end{tabular}

* Figures in parentheses indicate percentages of the total number of strains examined in the year.

Table 2. In vivo change of resistance patterns in S.johannesburg in individual cases

The data in this table are from cases from which two or more isolates of $S$. johannesburg were made.

\begin{tabular}{|c|c|c|c|}
\hline \multicolumn{2}{|c|}{$\begin{array}{c}\text { ASTCKSu-resistant } \\
\text { (38 cases) }\end{array}$} & \multicolumn{2}{|c|}{$\begin{array}{l}\text { ASCKSu-resistant } \\
\text { ( } 25 \text { cases })\end{array}$} \\
\hline $\begin{array}{l}\text { Resistance } \\
\text { pattern }\end{array}$ & $\begin{array}{l}\text { No. of } \\
\text { strains* }\end{array}$ & $\begin{array}{l}\text { Resistance } \\
\text { pattern }\end{array}$ & $\begin{array}{l}\text { No. of } \\
\text { strains* }\end{array}$ \\
\hline ASTCKSu & $64(60.5)$ & ASTCKSu & $2(3.9)$ \\
\hline ASCKSu & $7(6 \cdot 6)$ & ASCKSu & $48(94 \cdot 1)$ \\
\hline ASTCSu & $6(5 \cdot 7)$ & & \\
\hline ATCK & $2(1.9)$ & & \\
\hline $\mathrm{TCSu}$ & $2(1.9)$ & & \\
\hline ASTKSu & $1(0.9)$ & & \\
\hline TSu & $11(10.4)$ & & \\
\hline $\mathrm{T}$ & $2(1.9)$ & & \\
\hline ATSu & $1(0.9)$ & & \\
\hline ASSu & $1(0.9)$ & $\mathrm{ASSu}$ & $1(2.0)$ \\
\hline ATSu & $1 \quad(0.9)$ & & \\
\hline ST & $3(2.8)$ & & \\
\hline ASKSu & $5 \quad(4 \cdot 7)$ & & \\
\hline $\begin{array}{l}\text { Total no. of } \\
\text { subsequent } \\
\text { isolates }\end{array}$ & $106(100)$ & & $51(100)$ \\
\hline
\end{tabular}

* Figures in parentheses indicate percentages of the total number of subsequent isolates.

\section{Alteration of resistance patterns in vivo}

Since $S$. johannesburg was isolated repeatedly from a number of patients, changes in the resistance patterns of strains could be observed from individual cases (Table 2). When the first isolates were ASTCKSu-resistant, $40 \%$ of the subsequent strains showed up to 13 different patterns of resistance. However, from patients initially infected with an ASCKSuresistant strain, only $6 \%$ of the subsequent strains showed different resistance patterns. Thus the resistance pattern ASCKSu appeared to be more stable in vivo than the pattern ASTCKSu.

\section{Alteration of resistance patterns in vitro}

The ASTCKSu-resistance plasmids could be transferred in toto from $S$. johannesburg to recipient $E$. coli strains at frequencies ranging from $2 \times 10^{-3}$ to $1 \times 10^{-5}$ in overnight matings at $37^{\circ} \mathrm{C}$. Of the transconjugants, $41 \%$ showed a variety of resistance patterns different from that of the donor. The plasmids carrying ASCKSu resistances could also be transferred in 
Table 3. Frequency of progeny colonies with different resistance patterns obtained during daily subculture of resistant $S$. johannesburg parent strains

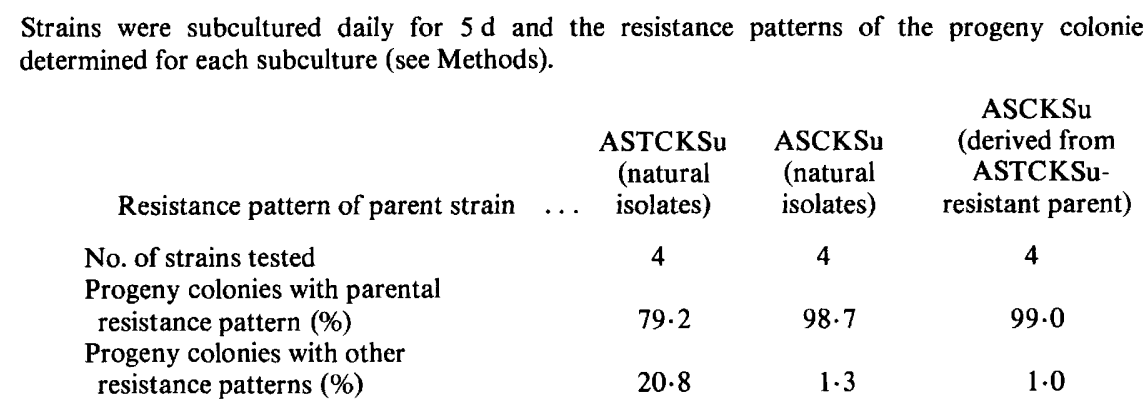

toto to recipient $E$. coli strains. However, plasmid segregants showing various resistance patterns other than ASCKSu were obtained at a lower frequency of $17 \%$. This suggested that during transfer plasmids carrying ASCKSu resistances were more stable than those carrying ASTCKSu resistances.

The stability of drug resistance markers was therefore compared during daily subculture of the ASTCKSu-resistant and ASCKSu-resistant strains of $S$. johannesburg (Table 3). Colonies becoming sensitive to one or more drugs were obtained at frequencies of $21 \%$ and $1.3 \%$, respectively. Similar studies were performed on the ASCKSu-resistant progenies of the ASTCKSu-resistant parents. Progeny colonies showing different resistance patterns were obtained at a frequency of $1 \%$ (Table 3). This supported the hypothesis that plasmids carrying ASCKSu resistances were much more stable than those determining ASTCKSu resistances.

\section{Incompatibility grouping of the $R$ plasmids}

Each of the eight plasmids in this study which coded for ASCKSu resistance and ASTCKSu plasmids that had spontaneously lost the T-resistance determinant were incompatible with F-lac and F-T and with the group FI plasmid R386, being completely displaced by the incoming standard plasmid. They were compatible with the other groups of plasmids mentioned in Methods. Thus it was concluded that these $S$. johannesburg plasmids were members of the FI complex.

Plasmids that originally coded for ASCKSu or ASTCKSu resistance but which had lost the $\mathrm{K}$ resistance marker were tested for compatibility with the non-autotransferring plasmid K-MP10 and with the FIme resistance factor TP243. Transconjugants were screened for the presence of the incoming and resident plasmids as described in Methods and both $S$. johannesburg plasmids were found to be incompatible with K-MP10 and with TP243. These plasmids were therefore assigned to the FIme subgroup on the basis of their incompatibility with the F factor and R386, and with K-MP10.

\section{Phage typing studies}

When ASCKSu or ASTCKSu plasmids were introduced into S. typhimurium type 36, lysis of the plasmid-carrying $S$. typhimurium transconjugants by 24 of the typing phages was reduced or abolished and the resultant pattern of phage lysis corresponded to that designated NC10 (Anderson et al., 1977). Similarly, acquisition of these plasmids converted S. typhi type A, sensitive to all the Vi-typing phages, into type 44 , which was sensitive only to phage 44. These restriction patterns in the respective hosts are typical of those produced by FIme plasmids and have previously been observed with FIme plasmids from S. typhimurium and $S$. typhi (Anderson et al., 1977). 


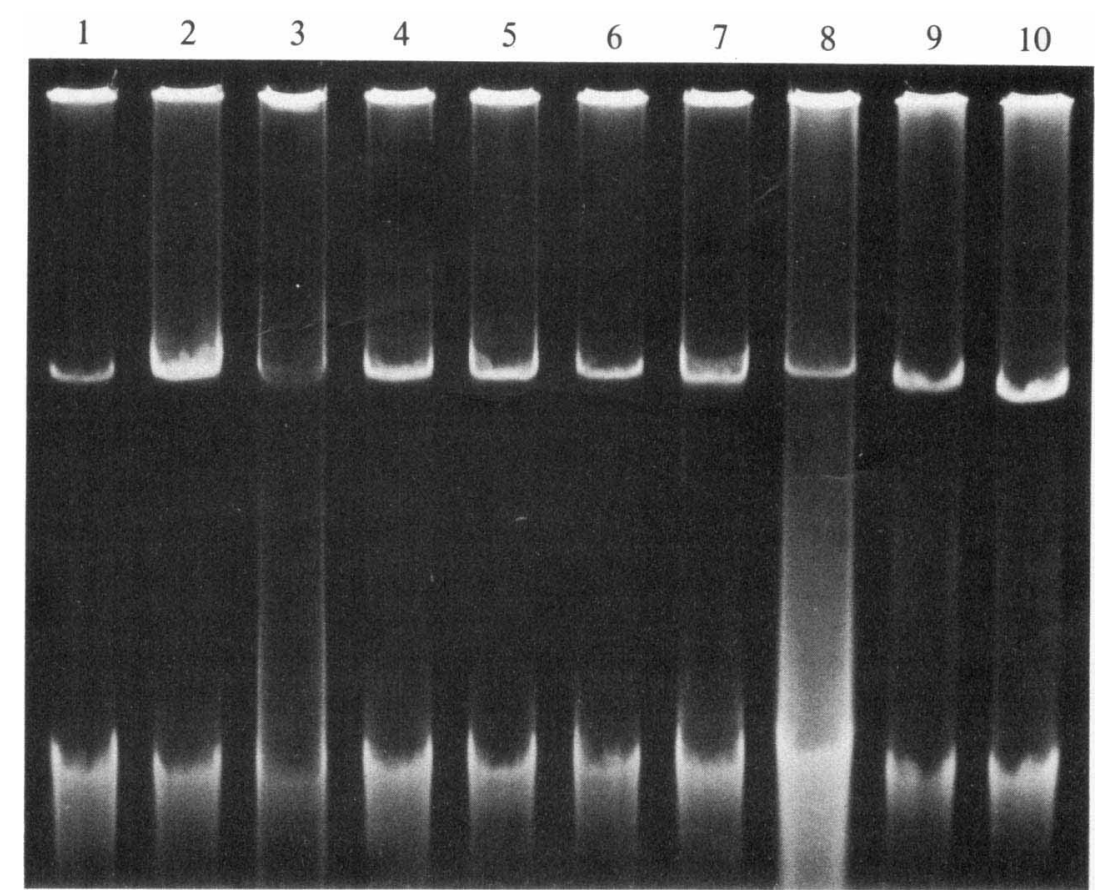

Fig. 1. Agarose gel electrophoresis of plasmid DNA in E. coli transconjugants. Tracks: 1, strain A (ASTCKSu-resistant); 2, strain B (ASCKSu-resistant); 3, strain C (ASTCKSu-resistant); 4, strain D (ASTCKSu-resistant); 5, strain $\mathrm{D}^{\prime}$ (derived from strain D, ASCKSu-resistant); 6, strain E (ASTCKSu-resistant); 7, strain $\mathrm{E}^{\prime}$ (derived from strain E, ASCKSu-resistant); 8, reference plasmid TP124 (120 Mdal); 9, reference plasmid TP181 (98.2 Mdal); 10, reference plasmid RA1 (86 Mdal).

\section{Characterization of the $R$ plasmids by agarose gel electrophoresis}

Gel electrophoresis of plasmid DNA demonstrated the presence of a large plasmid in strains of $S$. johannesburg (results not shown) and in $E$. coli transconjugants which had acquired the drug resistance pattern of the donor. These $\mathrm{R}$ plasmids coding for ASCKSu or ASTCKSu resistance varied in size but were around 110 megadaltons (Mdal). Figure 1 shows the size estimation by agarose gel electrophoresis of plasmid DNA from E. coli transconjugants, with reference to plasmids of known molecular size.

In order to examine the molecular similarity of these $\mathrm{R}$ plasmids, they were subjected to enzymic cleavage by the restriction endonucleases EcoRI or HindIII, and the DNA fragments generated were separated in agarose gels. The two plasmids chosen for this study were prepared from an ASCKSu- and an ASTCKSu-resistant strain. The two plasmids produced very similar restriction patterns (Fig. 2), indicating their molecular relatedness.

The FIme plasmids described in this paper were similar to those found in $S$. typhimurium (Anderson et al., 1977) and S. wien (McConnell et al., 1979) in their resistance pattern, molecular size and genetic instability. The wide distribution of the FIme plasmid-bearing $S$. typhimurium strains of apparently clonal origin in the Middle East, North Africa and Great Britain has prompted Anderson and his colleagues to suggest that these plasmids might contribute to the communicability and virulence of the host bacterial cells, in addition to their drug resistance. Our finding of the prevalence of these plasmids in $S$. johannesburg and the dramatic increase in the incidence of $S$. johannesburg in Hong Kong might add further weight to their argument.

The primary purpose of this communication is to illustrate the change of resistance patterns in a given Salmonella serotype, which was evidently due to the instability of the 


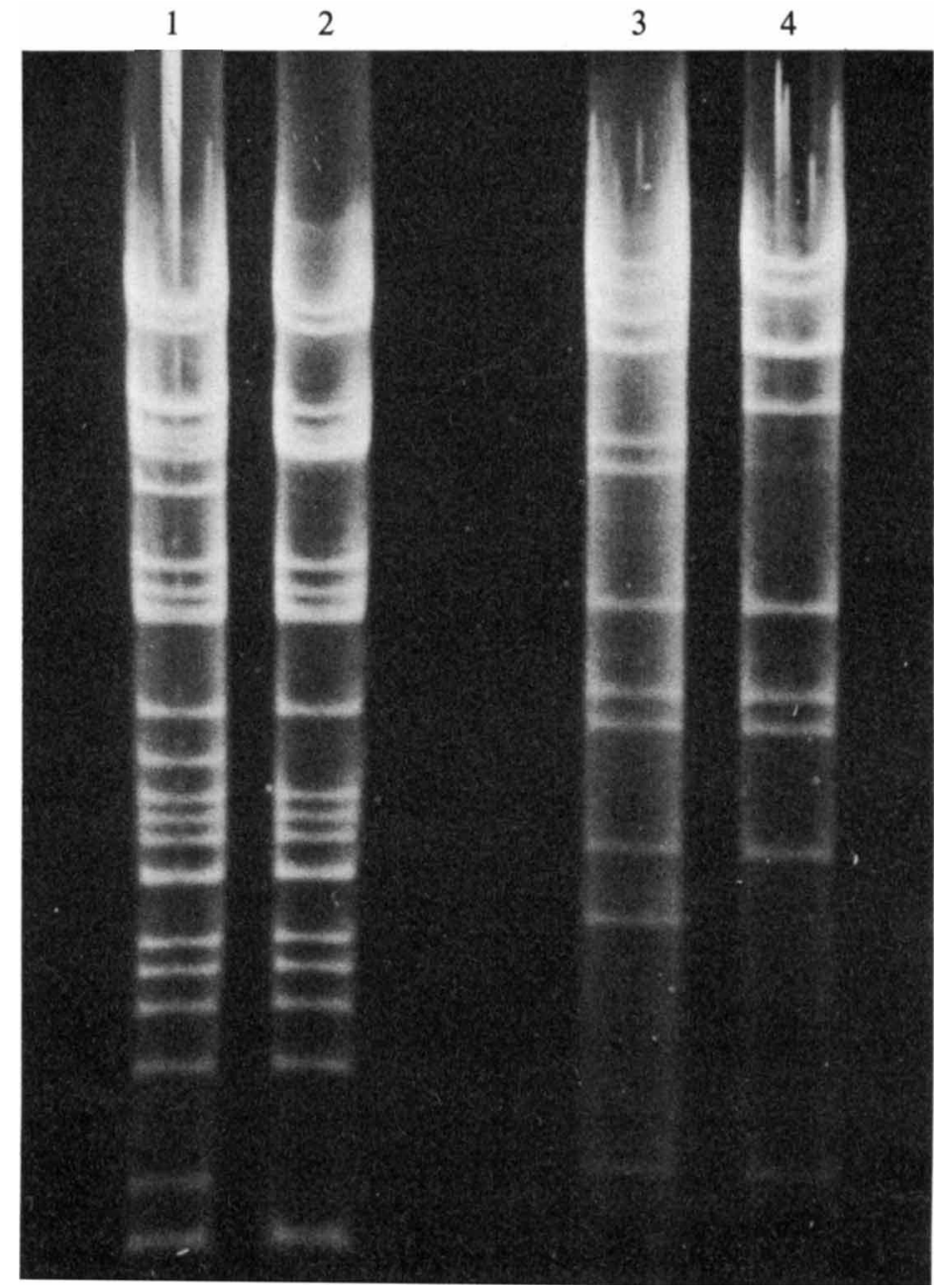

Fig. 2. Agarose gel electrophoresis of DNA fragments. Tracks 1 and 2 show EcoRI digests of a plasmid coding for ASTCKSu-resistance and ASCKSu-resistance, respectively. Tracks 3 and 4 show HindIII digests of the same plasmids as in Tracks 1 and 2.

ASTCKSu-resistance plasmid. This instability appeared to be associated with the presence of the T-resistance determinant, since its deletion from the four ASTCKSu resistance plasmids rendered it genetically more stable (Table 3). The reason for the initial predominance of the ASTCKSu-resistance plasmid was unclear since it was apparently not very stable. We suspect it was a newly evolved plasmid, formed, for example, by integration of two plasmids into one. The ASCKSu-resistance plasmids apparently evolved from the ASTCKSuresistance plasmids. Their molecular similarity indicated by restriction enzyme digestion and their belonging to the same FIme group support this view.

We are grateful to Dr R. W. Hedges, Department of Bacteriology, Royal Postgraduate Medical School, London, for his kind help in performing incompatibility grouping of the plasmids and many helpful suggestions, and to Dr B. Rowe, Director of the Division of Enteric Pathogens, Central Public Health Laboratory, Colindale, London, for his kind permission to allow one of the authors (J. Ling) to perform part of this study in his laboratory. This study was supported in part by the Medical Faculty Research Grant Fund of the University of Hong Kong. 


\section{REFERENCES}

ANDERSON, E. S. (1964). The phage typing of salmonellae other than $S$. typhi. In The World Problem of Salmonellosis, pp. 89-110. Edited by E. Van Oye. The Hague: W. Junk.

Anderson, E. S., Threlfall, E. J., Carr, J. M., MCConNell, M. M. \& SMITH, H. R. (1977). Clonal distribution of resistance plasmid-carrying Salmonella typhimurium, mainly in the Middle East. Journal of Hygiene 79, 425-448.

Callow, B. R. (1959). A new phage typing scheme for Salmonella typhimurium. Journal of Hygiene 57, 346-359.

Chau, P. Y., Wong, W. T. \& FoK, Y. P. (1978). Resistance to chloramphenicol and ampicillin in Salmonella johannesburg in Hong Kong: observation over a five year period 1973-1977. Journal of Hygiene 81, 343-351.

Craigie, J. \& Felix, A. (1947). Typing of typhoid bacilli with Vi bacteriophage. Lancet $i, 823-827$.

Greene, P. J., Betlach, M. C., Boyer, H. W. \& GoodmaN, H. H. (1974). The EcoRI restriction endonuclease. Methods in Molecular Biology 7, 387-398.

HaNsen, J. B. \& Olsen, R. H. (1978). Isolation of large bacterial plasmids and characterization of the P2 incompatibility group plasmids $\mathrm{pMG1}$ and pMG5. Journal of Bacteriology 135, 227-238.

Humphreys, G. O., Willshaw, G. A. \& ANDERSON,
E. S. (1975). A simple method for the preparation of large quantities of pure plasmid DNA. Biochimica et biophysica acta 383, 457-463.

MCCONNELL, M. M., SMITH, H. R., LeONARdopoulos, J. \& ANDERSON, E. S. (1979). The value of plasmid studies in the epidemiology of infections due to drug-resistant Salmonella wien. Journal of Infectious Diseases 139, 178-190.

Smith, H. R., Humphreys, G. O., Grindley, N. D. F., Grindley, J. N. \& Anderson, E. S. (1973). Molecular studies of an $f^{+}$plasmid from strains of Salmonella typhimurium. Molecular and General Genetics 126, 143-151.

Threlfall, E. J., Carr, J. M. \& Anderson, E. S. (1976). Compatibility relations of resistance plasmids in Salmonella typhimurium of Middle Eastern origin. Proceedings of the Society for General Microbiology 3, 88.

Willshaw, G. A., Smith, H. R. \& Anderson, E. S. (1978). Molecular studies of FIme resistance plasmids particularly in epidemic Salmonella typhimurium. Molecular and General Genetics 159 , 111-116.

Willshaw, G. A., Smith, H. R. \& Anderson, E. S. (1979). Application of agarose gel electrophoresis to the characterization of plasmid DNA in drugresistant enterobacteria. Journal of General Microbiology 114, 15-25. 